"The treaty's going to give the recognition that this wasn't right" Optimism and pessimism in non-Indigenous attitudes to treaties in Australia

\title{
Introduction
}

Like other settler-colonial societies, Australia over the last half-century or so has been the site for a lengthy and involved discussion about the need for Indigenous and nonIndigenous peoples to reconstitute the relationship between them, recognising past injustices and forestalling future conflict. Unlike those other countries, however, Australia and its states lack a history of treaties and treaty law to ground that discussion. While the idea of treaty has been highly politicised over time, what such negotiations and agreements might mean in practice-what eventual treaties might do (in terms of recognition and reparation)-remains vague. This lack of certainty provides scope for latent non-Indigenous attitudes to be activated in relation to any proposal for making treaties in Australia.

In recent years, the call for a treaty or treaties was revived during a decade-long campaign centred on an ill-defined proposal to 'recognise' Aboriginal and Torres Strait Islander peoples in the Australian Constitution. This proposal was advanced through several inquiry processes and a government-funded public relations organisation, Recognise, which attempted to seed a movement in support of constitutional recognition. As the years of the campaign rolled on, however, and the recognition proposal itself became no more concrete, a growing number of Aboriginal and Torres Strait Islander people began to express their reservations about constitutional reform, and to again call instead for a treaty or treaties (Maddison 2017). While opposition from the federal government to such proposals has remained steadfast, several sub-national jurisdictions have, for the first time, taken up the call for treaty: in Victoria from $2016^{\mathrm{i}}$ and briefly in South Australia before a change of government put an end to the process there. In both New South Wales and Tasmania the Labor Party in opposition suggested they would advance a treaty should they win office, although both subsequently failed to in their 
election bids. In mid 2018 the Northern Territory committed to advancing a treaty in that jurisdiction and in early 2019 appointed Yawuru man and retired university professor Mick Dodson as Treaty Commissioner.

Despite such political moves, little is known about the attitudes of non-Indigenous people to the idea of treaty-making in Australia. This is a concern because, while nearly all significant changes to the Indigenous affairs landscape in Australia have come through the actions of political elites and courts, ostensibly progressive approaches have been subject to forms of counter-claim making by regressive non-Indigenous actors, often invoking the (allegedly oppositional) views or interests of the wider public in support of their views: the statutory land rights debate of the early 1980s, for example, or the culture wars precipiated by the Mabo and Wik judgments and the passage of the Native Title Act in the early 1990s. Consequently, considering non-Indigenous attitudes to treaty is an important task as these sub-national initiatives move from discussion and planning to negotiation and implementation. This article begins to address a lacuna in understanding of non-Indigenous attitudes and considers whether these may be a potential, if volatile resource for policy advocates of treaty-making.

Researching attitudes is inherently discursive work. Attitudes are formed in response to discourse, they manifest as discourse, and they predispose or prejudge further discourse to come. Even under circumstances of limited knowledge or confidence, as we see with non-Indigenous feelings about Aboriginal reconciliation in Australia, such attitudes as people are able to formulate with any degree of coherence are present in the things they say to each other. This article reports on focus groups that draw out attitudes to state-based treaties in the context of a largely stalled Australian project of national reconciliation. They also reveal important ways that discussion about treaties and treatymaking can intersect with non-Indigenous identities. Importantly, they show that the concept of treaty is profoundly open for these non-Indigenous participants: they use the word in ways we may characterise as profoundly non-committal.

In the second half of 2017, the authors conducted a series of twelve focus groups that brought together non-Indigenous Australians in South Australia and Victoria, to explore their knowledge about, and attitudes towards, the proposals that their respective state 
governments would negotiate a treaty or treaties with the Aboriginal peoples in that state. These focus group discussions occurred at a moment when debate about treaty was still occurring at Commonwealth level (following the Statement from the Heart, discussed below), and while processes towards treaty/-ies were in fact underway in these two state jurisdictions. Yet while the focus groups revealed some familiarity with the history and concept of treaties in other settler-colonial societies, participants demonstrated very little understanding of the content of existing treaties, and almost no awareness that Australian state governments could or were seeking to make them.

Despite the limited awareness among participants, the focus groups also showed that there was sufficient consciousness among participants that they were able to formulate ideologically coherent responses to the questions that the focus group facilitator asked them - regarding whether their governments should negotiate treaties with Indigenous people/s, and what the content of such treaties should be. This article shows how the topic of treaty-making is discussed as an ideational dichotomy for non-Indigenous Australians-who are struggling to formulate a position on treaties, but in the absence of adequate knowledge about what these might involve. Awareness of the initial treaty discussions happening in Victoria and South Australia became a prompt either for optimistic ideation - typically an urgency to do something at a state level that might circumvent stalled debates at a Commonwealth level - or for pessimistic ideation typically a view that Australian state governments (as opposed to the Commonwealth) are not the correct level to make meaningful treaties, often compounded by a view that it is too late in history for Australia to strike treaties at any level of government.

Within these discursive frames, governments may find reasons to be both confident and apprehensive about non-Indigenous community support for state-based treaties. On the one hand, our focus groups show, arguments that treaties can enable a better future - especially a more prosperous one - for Australia and Australians have the greatest observable effect in moving discussions from a pessimistic to an optimistic frame. The more optimistic groups are conspicuously more conscious of this enabling dimension. Interestingly, the proposition that treaties can mobilise a truer account of the past does not conspicuously motivate greater resistance to them.i ${ }^{\text {ii }}$ On the other hand, suggestions that treaties might cause a redistribution of resources away from non-Indigenous people 
cause the greatest observable fear among participants-hence they prompt the greatest resistance from pessimists. In particular, arguments that treaties might 'right the wrongs of the past' prompt very cynical responses (rhetorics of disengagement) from pessimists.

This article extends earlier work conducted with support from the Australian Research Council's Discovery scheme (Maddison, Clark, and de Costa 2016). In the next section, it relates some of the background for this research, especially our reasons for researching non-Indigenous understandings and attitudes in the context of state government initiatives. The following section of this article discusses our methodology for the focus groups reported here, heavily informed by the methodology we published in Maddison et al. (2016). This entails a conscious focus on evidence of reflexive selfawareness from participants, moments where they openly discuss their identities as nonIndigenous people. Next, in our discussion of findings, we focus on the relationship between affect and ideation in the emergence of participant attitudes. Our study draws us to focus particularly on similarities and differences between locations and between the age cohorts of participants-both axes of distinction offer meaningful insight into the potential for meaningful community discussion around state treaties.

\section{Australian resistance to treaty/ies}

In other settler colonial contexts, treaties have long been used as a means of reaching a settlement between Indigenous peoples and colonisers. They are formal, negotiated agreements, that acknowledge Indigenous peoples as the original owners and occupiers of the land (Hobbs 2016: 1). Their content varies considerably, most especially between historical and contemporary treaties-but in general terms they tend to focus on land, resources, and the recognition of Indigenous self-determination, representation, and decision-making.

While treaties are not a formal part of Australian law and a part of colonial history, the desire for a treaty or treaties between Aboriginal and Torres Strait Islander peoples and the settler state has been a longstanding aspect of Indigenous political mobilisation. Moreover, non-Indigenous peoples have taken up the idea of making treaties or agreements with Indigenous peoples in Australia for their own purposes. 
The first instance of these has come to be known as the Batman Treaty, an 1835 attempt to transact a private land sale between members of the political elite from the colony of Van Diemen's Land (now Tasmania) and members of the Kulin Nation, the traditional owners of the Port Phillip region around present-day Melbourne. The nonIndigenous proponents, who came to be known as the Port Phillip Association, were plainly motivated by the possibility of acquiring good pastoral land, which had become expensive in Tasmania (Attwood 2009: 17). However, Attwood argues that they had other motivations in choosing to see their effort as a form of negotiated agreement, including knowledge of the history of Britain's granting of territorial rights to private corporations in North America prior to the Royal Proclamation of 1763 (Attwood 2009: 25-28). Furthermore, Attwood suggests that the members of the Port Phillip Association also had a "psychological need... (and) realised they were seeking to appropriate the land from its rightful owners, and they were troubled by this knowledge." This was an appreciation of the arguments of evangelical Christians of that era, that treaties were a way to promote peaceful relations on the colonial frontier (Attwood 2009: 36-39). In repudiating the deeds of title drawn up by the Port Phillip Association and allegedly agreed to by the Kulin in June 1835, the colonial government of New South Wales (which asserted its sovereignty) did not rely so much on philosophical and legal reasoning as it did on the existing relations of power on the ground, where the militarised state had had no reason to treat with Indigenous peoples from its origins as a penal colony in the $1780 \mathrm{~s}$; indeed, its land granting operations had proceeded with this confidence for almost 50 years by this point and a radically new approach would have been highly problematic in administrative terms (Attwood 2009: 93-96).

In 1979, the National Aboriginal Conference (NAC), a national representative body created by the federal government to provide a forum for the expression of Indigenous views, recommended that a Treaty of Commitment be entered into between the Australian Government and Aboriginal nations. This proposal recommended that a word from an Indigenous language should be used to describe this process, and chose the word 'makarrata', discussed further below. The NAC passed a resolution in April 1979, calling for a treaty that would: ... be executed between the Aboriginal Nation and the Australian government (Australia, Parliament, Senate, and Standing Committee on Constitutional and Legal Affairs 1983). In response a collective of high-profile settlers - whose 
supporters included leading conservatives such as Geoffrey Blainey and Richard Alston the Aboriginal Treaty Committee (ATC) formed to express a public non-Indigenous interest in treaties, including taking out a large advertisement in The National Times of August 25, 1979, calling on government to “... enable the National Aboriginal Conference to summon a convention of representatives nominated by Aboriginal communities ... who would propose the bases of negotiation and how any settlement should be confirmed ... organise the negotiations ... (and) submit any Treaty, Covenant or Convention to Parliament for ratification" (Harris and ATC 1979: 13).

At the time, both the Coalition Commonwealth government and the opposition Australian Labor Party were open to the concept in principle. The then Prime Minister Malcolm Fraser indicated his "preparedness to discuss the concept of a treaty."iii His government soon averred from the term "treaty" after advice from the Attorney-General, relying on the judgment in Coe $v$ The Commonwealth, which stated that "there is no aboriginal nation, if by that expression is meant a people organised as a separate State or exercising any degree of sovereignty." iv An alternative had been found by the NAC in the Yolngu concept of a "makarrata", meaning the end of hostilities. In response the government outlined their position: negotiations take place on the basis of "the special place of ATSI people within Australian society as part of one Australian nation." Moreover, the Commonwealth was not prepared to act unilaterally and would have to engage the States (Senate Report 1983: 18). However, they referred the entire matter to the Senate Standing Committee on Constitutional and Legal Affairs which reported two years later, concluding that the only path to a substantive and enduring agreement would be through constitutional entrenchment. Furthermore, the Senate Committee heard from many witnesses and advocates for the makarrata but observed "limited understanding of the concept" amongst both Indigenous and non-Indigenous advocates. As a consequence, the Senate Report recommended a process of community education and discussion (Senate Report 1983: 151-156).

A few years later, the Treaty '88 campaign brought together a convergence of around 50,000 Aboriginal people (nearly a fifth of the total national population at that time) to disrupt the 26 January bicentenary celebrations in Sydney (Burgmann 2003: 66), ensuring the question of treaties stayed on the national agenda. Also in 1988, the then 
Labor Prime Minister, Bob Hawke, received the Barunga Statement, which called on parliament "to negotiate with us a Treaty recognising our prior ownership, continued occupation and sovereignty and affirming our human rights and freedom." In response, Hawke signed a statement in which he undertook to negotiate a treaty with Indigenous people-a promise on which he would later renege.

The creation of the Council for Aboriginal Reconciliation (CAR) became the way that the Commonwealth took up the recommendation of the Senate Report to undertake community education. However, the fundamental goal of that was no longer explicitly to create support for an agreement but the vaguer project of reconciliation and "sharing history." The question of a treaty or formal agreement was revisited in 2000 when the CAR concluded its final Document Towards Reconciliation recommended that a treaty be negotiated. However, the then Coalition Australian government foreclosed discussion, rejecting a treaty on the grounds that '...such a legally enforceable instrument, as between sovereign states, would be divisive, would undermine the concept of a single Australian nation...' (Commonwealth Response to the Council for Aboriginal Reconciliation Final Report (2002: 23). Prime Minister John Howard notoriously stated that "an undivided united nation does not make a treaty with itself" (Laws 2000).

At the national level, discussion of a treaty lay dormant after 2000, while a Conservative agenda of "practical reconciliation" - an explicit rejection of all measures seen to be "symbolic" - became national policy. The return to power of the ALP in 2007 revived the idea of formal national processes, which soon centred on a vague campaign for Indigenous "recognition" in the Australian Constitution. During the period between 2011 and 2016, Indigenous voices critical of the 'Recognise' campaign, and supportive of a treaty or treaties, became louder and louder, eventually persuading the federal government to support a so-called “black process” (see Maddison 2017). The Referendum Council undertook a series of thirteen deliberative dialogues with Aboriginal and Torres Strait Islander people across Australia, culminating in a convention of 1200 Aboriginal and Torres Strait Islander people held at Uluru in May 2017. At the conclusion of the convention, delegates endorsed the 'Statement from the Heart' (Referendum Council 2017), which called for a constitutionally enshrined Voice to Parliament, and for the permanent establishment of a Makarrata commission - a body to oversee the making and 
honouring of treaties with Aboriginal people and to "oversee a process of truth-telling about Australia's history and colonisation."

Just months after the Statement was made, however, Prime Minister Malcolm Turnbull rejected the Referendum Council proposals. His focus was primarily on the proposed Voice (the only part of the statement that required constitutional change), which Turnbull saw as both undemocratic (an alleged "third chamber of parliament") and without popular support. The evidence for that view was not tested.

In the context of these ongoing processes and at times very heated debates, the push to develop subnational instruments emerged, and the scale and scope of these discussions throughout 2017 meant it was a time when the question of treaty was morethan-usually canvassed in Australian news media and other public discourse. At various moments over the last four years, the Northern Territory, South Australia, Victoria, and Western Australia have each committed to opening treaty negotiations between the Crown and the Aboriginal nations in those jurisdictions. In our research and in this article, we focus on two of those jurisdictions: Victoria and South Australia, noting that soon after we conducted the focus groups for this article, a change of government in South Australia's 2018 election resulted in the indefinite suspension of treaty processes in that state in favour of what new Premier Stephen Marshall described as a 'state-wide plan' with 'defined outcomes for Aboriginal people' (ABC News 2018). Prior to this, however, both governments had advanced extensive research to determine the number of treaties to be negotiated in each jurisdiction, based on the views of Indigenous peoples in those jurisdictions as to the number of Aboriginal groups, clans, or nations that should have representative standing.

Finally, it has been argued recently that the next putative treaty struck in Australia was completed in 2018, the South West Native Title Settlement between the Noongar people and the government of Western Australia. WA Government proponents of the agreement spoke of it as "historic and overdue", while the supportive Opposition went further, calling it a "a classic treaty... finding a way forward together and recognising each other's sovereignty." (Hobbs and Williams 2018, 34-35). 
Reviewing this history, one cannot conclude that there is no interest in treaties amongst non-Indigenous peoples in Australia, nor that non-Indigenous peoples are universally or even widely opposed to them. Indigenous Australians have consistently sought a formal agreement but governments have never followed through, even against their own advice about the desirability of formal agreements and the need to support the community to understand what treaties entail. Moroever, it is evident from this history that in its sporadic considerations of treaties, non-Indigenous focus has been consistently on the challenges they involve (constitutional change, multi-jurisdictional issues in the Federation) or the alleged problems they give rise to (separatism, meaningless symbolism). There was no significant effort to inform Australians about the merits of treaty-making, including for the community as a whole, nor to thoughtfully place the Australian experience in a long history of international treaties.

Without question, it seems inappropriate to suggest that Aboriginal and Torres Strait Islander peoples should wait for, or should pursue, the support of non-Indigenous peoples in the negotiation of political agreements between their polities (the scale of which are yet to be agreed) and the occupying settler state. On the other hand, the evidence of treaty and agreement discussions in Australia suggests that the views of nonIndigenous Australians will be invoked anyway by those who object to the Victorian and other government's policy, and will be done in ways that construct non-Indigenous opinion as both coherent and opposed to agreements.

In this research, we have taken the opportunity to explore with non-Indigenous people how they understand their own stake in these negotiations and in the idea of a treaty for their state. This ranges from some very basic scoping of awareness through to more nuanced explorations of predisposition and ideology. In large part, we have sought to draw out the types, forms, or elements of treaties and treaty-making that can potentially give voice to non-Indigenous aspirations for the future of their relationships with Aboriginal neighbours, friends, fellow workers, and family.

\section{Methodology}

In a set of focus groups conducted during 2014, we had asked non-Indigenous Australians to reflect on their understandings of Aboriginal people and cultures, including the 
question of whether they felt a 'responsibility to engage' in some sense or to some extent in contemporary politics or efforts towards reconciliation. For this research, by asking about understandings of treaty in 2017, we sought to maximise the advantages of a focused topic in a closely related area. With ethics approval from the University of Melbourne, we commissioned a market research firm to recruit participants and to facilitate and record pairs of focus groups at three sites in each of Victoria and South Australia. Those sites were Bairnsdale, suburban Melbourne, and Shepparton in Victoria, and Mt Gambier, Port Augusta, and suburban Adelaide in South Australia.

Participants were informed that they were invited in their capacity as non-Indigenous Australians, and they were aware that the discussions would focus on views about Aboriginal reconciliation and related matters. We tailored the discussions slightly to maintain state relevance, ${ }^{\mathrm{v}}$ but essentially all groups followed the same semi-structured list of topics and sub-issues. These were formulated by the researchers in consultation with the facilitator. They were focused on three themes, introduced in this order:

- Cultural and historical knowledge about Aboriginal people, including the confidence of participants to identify and share that knowledge.

- Awareness of treaty as a concept - awareness of treaties in general and of past or present views on whether Australia needs one or more treaties with Aboriginal people.

- Views about a state-level treaty that their state government would negotiate on their behalf, including the threshold question of whether it is an attractive or useful option, plus the subsequent questions of what matters a state treaty should and should not include.

At each location, as with previous research, we staged two focus groups. But whereas in previous research we have divided such twinned focus groups by participants' countries of origin - born in Australia versus born outside Australia (Clark, de Costa, and Maddison 2016) or born in Canada versus born outside Canada (de Costa and Clark 2015) - for this stage of the research we instead divided each site by age, with an under40 age group and an over-40 age group. We wanted to ensure a space in which all participants felt sufficiently comfortable to share their views, and age differences can 
create perceptions of unequal knowledge or life experience that can pose a particular challenge to that strategy. Dividing groups by age thus accords with methodological scholarship around the conversational dynamics of knowledge asymmetries (e.g. Otten and Geppert 2009).

The market research firm recruited participants by telephone, using randomised telephone book entries for landlines and social media for mobile phones. We offered each participant a $\$ 100$ honorarium. No recruiting approach is without its limitations, however the spread of respondents by a range of demographic characteristics for these focus groups was robust. Most valuable for our purposes was that we were able to fill all groups with participants who predominantly did not know each other beforehand (even at the rural sites). Of the twelve groups, ten had between eight and ten members, while one (under-40, Mt Gambier) had five and another (under-40, Bairnsdale) only four. The market research leader facilitated all twelve focus groups, with a member of our research team present as an observer each time.

Analytic methods for this research have primarily drawn on direct observation of the groups (including observer notes), on immersive analysis of the recordings and transcripts, and on parsing of the transcripts using AdTAT. ${ }^{\text {vi }}$ We have not systematically coded the transcripts for this article, simply because it has not particularly suited our analytic approach here. In every case, we have made a conscious effort to align the content, form and strategic agenda of remarks-exploring the meanings these conversations have exchanged by asking what the participants have said, how they have said it, and what goals their remarks were driving at. Taking a concordance view has helped us to perform this analysis comparatively, mindful of how a given participant's phrasing stands in comparison to the phrasing of others.

\section{Main findings}

At this barely-yet-informed stage of non-Indigenous discussion about the treaty processes in South Australia and Victoria, the focus groups offered a wealth of evidence that some attitudes are still fluid - especially on the core question of supporting or opposing treaties. Support for treaty, where it took hold in these groups, was largely associated with impatience about "waiting for a national initiative" - an unconcealed 
rebuke to the policy stalemate at the Commonwealth level. This was more strongly evident among the under-40 groups, and noticeably stronger in Shepparton and Port Augusta than the other locations. Opposition to treaty, where it gathered consensus in these groups, was typically a pessimistic view about the prospects for change and a lack of faith that state governments can or should be the initiators of such fundamental changes to relationships that have been interpreted as central to national self-definition. This pessimistic view was more strongly evident among the over-40 groups, and noticeably stronger in Bairnsdale and Mt Gambier than the other locations.

Across the focus groups, the affective dimensions of participant contributions corresponded faithfully to the optimism/pessimism dichotomy. In very bald terms, expressions or exchanges of optimism were characterised by avowals of energy, even impatience, to make change happen. Some participants were very keen for progress, almost regarding the focus group process itself as an opportunity to drive it. As this indicative example from the under-40 Port Augusta group shows, that proactive ethos flows into a desire for states to seize the opportunity of treaty to break through the political stalemate of Aboriginal reconciliation:

Not just in the language groups of the state, but each state might as well go through their own process as well, because as we've seen with a lot of things we've seen, what happens in the middle of Canberra will be different to how it's actually rolled out in Alice Springs or something like that. So, I think it's great that South Australia and Victoria are all deciding, even if they're doing it because they can't be bothered waiting for a national initiative, that they get the ball rolling.

In equally bald terms, however, the expressions or exchanges of pessimism were characterised by willingness to delegate the challenge of Aboriginal reconciliation to the federal (but not the state) government. These participants tend towards a singular version of Aboriginal people and cultures, typically imagining them as living somewhere remote rather than nearby or as potential neighbours. Such a delegation of one's stake in the situation (cf. de Costa and Clark 2015) requires an abstract and distant government to take charge of negotiating with an abstract and distant population. Australia's federal 
system is configured to support such logic, as this over-40 participant from Adelaide related it:

The Commonwealth I think has to take the lead on it [treaty-making], but the way they drag their feet with a lot of different things, state-based seems to move forward in certain directions. But [fellow-participant] is right. If South Australia does one thing and the Northern Territory's saying, well, that doesn't exactly suit what we're thinking. Western Australia comes along and says ... there then comes a stage where there's going to be some sort of conflict. It might be minor, but it's still, sort of going forwards to try and go backwards again.

In a very general sense, it was clear that the older participants were more inclined to engage in these focus groups pessimistically than the younger. It was also clear that participants in those rural towns with older populations (and where we struggled to fill numbers in the younger groups), Bairnsdale and Mt Gambier, were more inclined to the pessimistic view, while the greatest optimism was in Shepparton and Port Augusta. Thus the too-easy assumption that pessimistic discourses increase in proportion to age came unstuck on sentiments such as these from the Shepparton over-40 group. This participant displays quite intricate knowledge about the localism and complexity of Indigenous politics, and seems to suggest that treaties would be a good thing - but expresses concern about the ways in which less supportive people could be put off:

I think it's gotta be Indigenous Aboriginal nation, not just, you know, a group in Gippsland or a group in Northern Victoria or Western Desert, somewhere like that, 'coz otherwise then you'll get factions there between the Indigenous. And then I think if it cottons on, the Europeans or non-Indigenous - never a correct way to say all these things - but you know, they cotton on that, 'oh yeah, you know, reparation or something like that', you know, this treaty, I think it'll put people that already feel, you know, offside with them, that they get a lot, it'll put 'em off even further. They're going to have to be really, really careful how they sell it.

The above quotations reflect relatively uncontentious moments within their respective group conversations. Equally revealing, however, are moments when a 
participant offers a view at odds with what passes before or after. From the Adelaide over-40 group, one participant's cynicism about reconciliation and apology was clearly more extreme than his colleagues were comfortable with (it was a group that seemed evenly divided between optimists and pessimists). For most of the conversation he sat silent with his arms crossed, but he offered this clear rationale for the pessimistic view, quite critical of what others had said, and which nobody was willing to counter for the rest of the session:

I've got a more negative view, and I agree that there is a lot of troubles, but I don't agree it's all our fault. I worked in the courts department for many years, and in that time I worked a lot of time in children's courts, so I saw a lot of Aboriginal teenagers coming through, and was actually responsible for cutting one down who tried to hang himself several times. I had a talk with him and his family afterwards. It was back in the early 90s when all the death in custody thing all flared up, so my view has been more negative. They don't come to court for singing too loud in the church. Do you know what I mean?

There are not corresponding examples of optimists standing out from a group of pessimists during any of these twelve focus groups. Instead we notice that optimists show a stronger impetus to manage the inputs of other group members, correcting each other on points of nuance and substance alike, as in this exchange between two from the under40 group in Melbourne:

S: To say that [teaching colonial history] would be too heavy for year eights -in year eight I was learning about World War II and World War I and all the ...

H: I didn't say too heavy, I said heavy.

S: Okay, yeah sure, I'm not accusing you, yeah I definitely think that shouldn't be an excuse to not teach it.

One factor cut across the ideational dichotomy in ways we did not expect, namely the attitude towards historical 'truth-telling.' It was a matter that emerged often, with both 
optimists and pessimists acknowledging its importance for any meaningful type of reconciliation. That comes as no surprise when pronounced by optimists, perhaps-such as this response from the under-40 group at Shepparton:

I know that what we learnt at our school was pretty inaccurate. The thing that sticks out to me, the violence. You know, you hear about all that, the Stolen Generation and stuff, but they even, white people even buried foot first, buried some Aboriginal people foot first, just leaving their head above the ground, and had horses kicking the heads of Aboriginal people. Stuff like that, so it was much more vulgar than what we actually learned.

Here the participant is choosing optimism based on the common assumption that greater knowledge of the historical violence of colonialism will promote a stronger desire among non-Indigenous people to attend to the relationship with Aboriginal and Torres Strait Islander peoples. Yet participants within highly pessimistic groups also considered it important to acknowledge colonial violence, such as in this example from the over-40 group in Bairnsdale, using terms reminiscent of prime minister Paul Keating's 'Redfern Park Speech' (Keating 1992):

I think it's just a recognition of-like, we said sorry. We said sorry for the stolen generation, but it's not—-the treaty's going to give the recognition that this wasn't right. It wasn't land for the taking, it was actually, there was an invasion. It's never really been recognised as an invasion, that it was actually their land, and there has to be some sort of treaty that will, you know [recognise] that they actually lived here and they have rights. And we've always denied them those rights for years and years and years.

Apparent in both these examples is a pattern we have also observed in earlier research, in which non-Indigenous participants characterise their stake in focus group conversations along racial lines. In these particular discussions about the prospect for treaties between Indigenous people and the non-Indigenous settler state, participants were willing to employ a paradigm that foregrounded membership of either (not both) of these groups. Even where the participants questioned an 'us and them' division 
between Indigenous and non-Indigenous people, they still used it as their system of pronouns, their grammar for discussing the topic of treaty. An example is from the over40 group in Mt Gambier:

Well, I don't know. It all depends on the individuals, I suppose. When you get those that don't want to integrate or they want to be segregated still... Because it always seems to be us and them.

As we have previously noted (Maddison, Clark, and de Costa 2016), there is plenty of nervousness about using racialised terms in Australia, as in many other countries. There is a wide current of cynicism about political rights that flow from racial identities, which we would typically associate with the people who are pessimistic about reconciliation and treaties. And yet these terms offer great productive potential. In an abstract sense, naming this clash of interests must be a precondition for any genuine negotiations to manage it. More specifically, it is because the 'us' and 'them' categories in play are not just racial identities, but distinctions between Indigenous peoples and others that speak to questions of national identity and legitimacy. This research has asked non-Indigenous people to talk about the non-Indigenous stake in state treaties and in reconciliation more broadly; in response, all the participants have proceeded on the basis that there is such a stake. Non-Indigenous Australians are clearly ready to identify as such, for the purposes of these conversations about treaty and reconciliation.

The way participants typically signal their willingness to engage with their own racial or ethnic position is by avowing it. Much of the interest for our research, however, has been to track what people do next, to understand what conversational outcomes they work towards once they have declared their identities. Often it is to assert the importance of honesty about the violence of the past, as in the previous two quotes. Another common use of reflexively aware self-positioning in these groups was to claim personal connections to the issue under discussion. Participants who mention they have Aboriginal family, friends, work colleagues, and neighbours are intrinsically making this show of identity, as with this example from an over-40 participant in Port Augusta: 
I also from a personal perspective, um, my family's from more of an Afghan perspective, but I have a part-Aboriginal grandmother, and so therefore, I've never grown up as an Aboriginal person or identified as an Aboriginal person at all, but I sort of have got a lot of strong connections there.

This racialised awareness is not necessarily optimistic. It may inform a deep cynicism about the grounds for reconciliation, as with the rather common refrain that Aboriginal and Torres Strait Islander people were lucky to have been invaded by the allegedly relatively benign colonisers of the British empire. Participants across five of our groups express a version of this inherently supremacist trope:

P: But if the Indonesians got in here or the Japanese after the war, there'd be no Aboriginals.

J: It's true.

P: Because the Japanese would've annihilated every- that's what they tried to do in New Guinea. If it wasn't for Australians stopping them, it would've happened there.

"They" was also our way into concordance-based analysis of the transcripts. Taking every instance of the word (including "they're" and "they've," since these forms are also in the subject or nominative case), we charted the preceding 28 characters and the following 28 characters of transcript to look for common collocations. This was a filter we applied to predominantly optimistic and predominantly pessimistic groups at a whole-of-transcript level. ${ }^{\text {vii }}$ For example, the largely optimistic under-40 group in Shepparton used "they," "they're," and "they've" a combined 146 times. The grammar of these words generally mandates a verbal complement, and so we find 143 occasions when the complement is obvious. Of those 143, only 14 instances are negative clauses: 12 of these involve the adverb "not"; 1 spells out a bereavement ("they've lost their skills"); a final instance revolves around difficulty ("they struggle to understand"). If we compare this with the largely pessimistic over-40 group in Bairnsdale, we find 314 uses of the pronoun, of which 91 are negated within the same clause: in 49 instances that is a 
negation using "no," "not," or "never"; a further 42 negations use circumlocutions or euphemisms (most cases involve terms for loss, death, or breakage). Across all the groups, this pattern is indicative: both the frequency and the stylistic diversity of negations on the things that "they" do establish a tone for "our" attitudes towards "them." For all our earlier remarks about productive categories, a heavy reliance on talk about "them" is a marker for a discussion's general pessimism towards the notion of a treaty.

The usage-in-context of "treaty" is harder to distinguish by attitude or demographic. Analysing the most common word collocations in phrase clusters of up to five words shows us which words participants most often used in close association with the word treaty. In our transcripts, the first-ranked noun is "something"-which ranks $43^{\text {rd }}$. All other nouns rank below $100^{\text {th }}$ position. Instead, what we see is associations with empty words (for instance, the five highest-ranked collocations are "the," "a," "that," "to," and "and"), with personal pronouns (especially "it," "we," "you," and "they"), and with modal verbs (especially the subjunctive forms "would" and "should"). What this tells us is that the concept of treaty is not anchored in specific terms for these non-Indigenous participants; it is a profoundly open concept, defined more by its parties than by any notion of its content. This fundamental quality of the discourse stretches across all sites, younger and older. It does not seem to vary by attitude, nor signal any distinctive orientation towards the topic.

On the other hand, participants' openness to the recognition of violence, even of genocide, did not lead to any particular willingness to countenance reparations or redistribution of resources as components of treaty. Anxiety about the potential economic consequences of treaty is a main concern that the pessimists bring to their considerations of the ideational dichotomy, as in this example from the over-40 group in Melbourne:

If I can just comment ... What you say, okay, I can accept it, but if you look at demographics in Australia, you've got people from all over the world now here and they're all busy with their own problems with housing, jobs, etc. Why should I support having a treaty with Aboriginal people if it means that they're going to get something extra and I don't? If you're a politician and you don't have your base 
support, you don't have the numbers behind you to go out on that side because you're going to lose your place. That's what I think.

What this kind of statement suggests is that it is not only concern that treaty will not provide 'practical' benefit Aboriginal and Torres Strait Islander people that is fuelling a pessimistic response, but also that treaty might mean non-Indigenous people might be required to give something up for what is seen as 'no good reason.' Such attitudes have been in strong evidence in much of our earlier research as well, and suggest that, were the negotiation of treaty to require popular political support, such processes would likely derail very quickly.

\section{Conclusion}

Kombumerri philosopher Mary Graham describes the negotiation of treaties as a 'maturing process' for the states that do it. Graham suggests that there could be 'hundreds of treaties on the ground, perhaps on a national level there could be a charter of treaties, with a treaty commission that could oversee the legalities.' Importantly, Graham stresses, the content of each of these treaties 'would have to be in the hands of local people' (quoted in Koori Mail 2013: 18). Graham is here talking about local Aboriginal people, whether they identify by clan, nation, or language group — the scale of treaty negotiations is yet to be determined in any jurisdiction. But assuming that treaties are negotiated locally (broadly speaking the preferred Indigenous way of doing things) rather than at state level, then there is perhaps an important role for local non-Indigenous people, who may perhaps have a more embodied sense of these relationships.

At present, given the low recognition of treaty processes among non-Indigenous participants in this research, there is little clear evidence on which to evaluate the specific approaches that South Australia was, and Victoria is, taking to advance treaties in their respective jurisdictions. And yet, against intuitive assumptions about the low awareness of treaty processes, most of the focus groups we conducted were also marked by a personally felt sense of issues at stake: the optimistic frame wants state-level treaties to happen, because it believes the national-level policy stalemate is harmful; the pessimistic frame is anxious about any substantive redistribution of wealth or rights. 
It remains an open question as to whether sub-national jurisidictions ought to consider these views seriously before they have fully formed, in order to actively create a non-Indigenous constituency for the local treaty instruments. When our facilitator asked what the participants, as non-Indigenous Australians, thought a treaty in their state should involve, the answers were serious and thoughtful, but their suggestions were quite superficial. It is evident that non-Indigenous Australians have barely started to think through what their stake in such an instrument might be. Even the confident and talkative participants - "opinion leaders" in the discourse of some focus group exponents - were at a loss for words when our facilitator asked what they wanted to see in a treaty.

At present, both the form and content of sub-national treaties remain an open question. In Victoria the process is moving slowly, with a promise that the Aboriginal representative body to advance this work to the next phase will be formed by mid-2019. It is unlikely that the South Australian process will be revived. The Northern Territory, and indeed other jurisdictions, are still formulating an approach.

It will not be a matter for non-Indigenous people to determine the scale or content of state or territory level treaty negotiations - these matters are the business only of Indigenous peoples and the states with whom they will negotiate. As we saw in South Australia, however, the pessimistic frame can be mobilised for political ends, where a more "practical" approach is advanced as a more promising means of improving Indigenous lives. So while non-Indigenous people will not be considered stakeholders to treaty negotiations in the sense of having a seat at the table, they are stakeholders in the sense that their sentiments may be used by political actors hostile to the treaty agenda. Understanding the ideational dichotomies non-Indigenous people face as they resolve a position on the question of treaty may prove an important political resource as these processes continue to emerge and evolve.

With these dynamics in mind, we would conclude by reflecting on the opportunity for governments to improve the political prospects of their treaty initiatives, actively engaging non-Indigenous residents in discussions of their purposes. While there is clearly a constituency for government action that recognises inherited imbalances and injustices, if its express purpose is to offer a more prosperous and dependable environment into the 
future, there is also clearly a strong current of anxiety about depriving non-Indigenous people of their possessions or prospects in the name of reparations or 'payback' for past wrongs. There is much cynicism about reconstituting the political environment for the sake of a desire to make the past more palatable. These two lines of watchfulness easily trigger a sense of injustice that governments will seek to make special allowance for Indigenous people. Balancing the opportunities to cultivate non-Indigenous support for state treaties against the dangers of increased community resentment, we do not assume to comprehend all the strategic priorities of the governments involved, nor do we explore the potential for political rivals to damage the treaties by mobilising opposition to them. Rather, this research offers clear evidence that there is scope to mobilise opportunities for non-Indigenous support without exacerbating the concomitant anxiety and cynicism.

\section{References}

ABC News. 2018. 'SA government decides not to go ahead with Aboriginal treaties', 8 June $<$ http://www.abc.net.au/news/2018-06-08/sa-govt-decides-not-to-go-ahead-with-aboriginaltreaty/9851166>

Attwood, B., 2009. Possession: Batman's Treaty and the Matter of History. Melbourne: Miegunyah Press.

Australia, Parliament, Senate, and Standing Committee on Constitutional and Legal Affairs 1983. Two hundred years later: report by the Senate Standing Committee on Constitutional and Legal Affairs on the feasibility of a compact or 'Makarrata' between the Commonwealth and Aboriginal people. Australian Govt. Pub. Service, Canberra

Burgmann, V., 2003. Power, profit and protest. Sydney: Allen \& Unwin.

Clark, T., de Costa, R., and Maddison, S., 2016. Non-Indigenous People and the Limits of Settler Colonial Reconciliation. In: S. Maddison, T. Clark, R. de Costa, eds. The Limits of Settler Colonial Reconciliation: Non-Indigenous People and the Responsibility to Engage. Singapore: Springer Nature, 1-12. 
de Costa, R., 2006. A Higher Authority: Indigenous Transnationalism and Australia. Sydney: UNSW Press.

de Costa, R. and Clark, T., 2015. On the Responsibility to Engage: Non-Indigenous Peoples in Settler States. Settler Colonial Studies. 6 (3), 191-208.

Grant, S., 2016. Without a treaty and constitutional recognition, no Australian is truly free. The $\begin{array}{lllll}\text { Guardian, } & 14 & \text { June. } & \text { Available }\end{array}$ https://www.theguardian.com/commentisfree/2016/jun/15/without-a-treaty-andconstitutional-recognition-no-australian-is-truly-free. Accessed 22 October, 2018.

Harris, S. and Aboriginal Treaty Committee, 1979. "It's coming yet ..." an Aboriginal treaty within Australia between Australians, Aboriginal Treaty Committee, Canberra, p. 13.

Hobbs, H. and Williams, G., 2018. The Noongar Settlement: Australia's First Treaty. Sydney Law Review (40), 1-38.

Keating, P., 1992. Redfern Park Speech. YouTube. National Archives of Australia. Available from: https://www.youtube.com/watch?v=x1S4F1euzTw, accessed 22 October, 2018.

Koorie Mail, 2013. Treaty tops agenda at Congress forum. 19 August, p. 18.

Maddison, S., 2017. Recognise what? The limitations of settler colonial constitutional reform. Australian Journal of Political Science, 52(1). 3-18.

Laws, J. 2000. Interview with prime minister John Howard. 2UE Radio. 20 May 2000. Transcript: https://pmtranscripts.pmc.gov.au/release/transcript-22788, accessed 31 March, 2019.

Maddison, S., Clark, T., and de Costa, R., eds, 2016. The Limits of Settler Colonial Reconciliation: Non-Indigenous People and the Responsibility to Engage. Singapore: Springer Nature.

Mansell, M., 2017. After Garma, we must learn from the failures of the referendum campaign. The Guardian, 7 August. Available from: https://www.theguardian.com/commentisfree/2017/aug/07/after-garma-we-must-learn-fromthe-failures-of-the-referendum-campaign. Accessed 22 October, 2018. 
McKenna, M., 2018. Response to Correspondence. Quarterly Essay, (70). 65-69.

Otten, M., and Geppert, J., 2009. Mapping the Landscape of Qualitative Research on Intercultural Communication. A Hitchhiker's Guide to the Methodological Galaxy. Forum: Qualitative Social Research 10 (1). Available from: http://www.qualitativeresearch.net/index.php/fqs/article/view/1252/2710. Accessed 22 October, 2018.

Pearson, L., 2017. What is a Makarrata? The Yolyu word is more than a synonym for treaty. ABC News, 10 August. Available from: http://www.abc.net.au/news/2017-08-10/makarrataexplainer-Yolyu-word-more-than-synonym-for-treaty/8790452. Accessed 22 October, 2018.

Referendum Council, 2017. Uluru Statement from the heart. Available from: https://www.referendumcouncil.org.au/sites/default/files/2017-

05/Uluru_Statement_From_The_Heart_0.PDF. Accessed 22 October, 2018.

Stastny, A., Henriss-Anderssen, S., and Clark, T., 2016. The Poetics of Non-Indigenous Reflexive Self-Awareness: Strategies of Embodiment and Delegation in Focus Group Discussions in Australia. In: S. Maddison, T. Clark, R. de Costa, eds. The Limits of Settler Colonial Reconciliation: Non-Indigenous People and the Responsibility to Engage. Singapore: Springer Nature, 159-176.

Wilkins, D., 2002. American Indian politics and the American political system. Lanham: Rowman and Littlefield.

\section{Declaration of interest}

The authors of this article have been co-investigators in an Australian Research Council Discovery Project on 'Non-Indigenous Pathways to Reconciliation in Australia.'

\footnotetext{
i In June 2018 the Advancing the Treaty Process with Aboriginal Victorians Act was passed in the Parliament of Victoria. This historic legislation, the first of its kind in Australia, commits the Victorian government to
} 
creating and working with an Aboriginal Representative Body made up of traditional owners. The Representative Body will determine who in Victoria can negotiate a treaty or treaties and what will be on the table for negotiation.

ii This runs counter to a view expressed by Mark McKenna $(2018,66)$ : 'merely to suggest we should acknowledge the brutality of Australia's foundation was enough to make some Australians feel persecuted.' iii Letter to Kevin Gilbert, provided in Department of Aboriginal Affairs submission, no. 16, to Senate Report, p. 14; ALP Aboriginal Policy 1978, cited in Harris, 73-74.

iv Coe v. The Commonwealth of Australia and the Government of Great Britain and Northern Ireland (1979) 53 ALJR 403, (1979) 24 ALR 118, at para. 22.

${ }^{\mathrm{v}}$ In particular, for the Victorian focus groups we used a video specifically about the Victorian treaty process as a discussion prompt, while we used a video that focused predominantly on the South Australian treaty process for the discussions there.

${ }^{v i}$ AdTAT is a concordance-building software package freely available from the University of Adelaide. Working with transcripts, it enables researchers to see patterns of collocation between words and phrases. For this research it has been especially useful for revealing the words and phrases that participants most commonly use in the same breaths as designated keywords in the transcripts (such as our discussion of treaty-collocations in the next section.)

vii We applied AdTAT techniques to transcripts that we had modified to remove the professional facilitator's input from each sample. 


\section{University Library}

\section{- M M N E R VA A gateway to Melbourne's research publications}

Minerva Access is the Institutional Repository of The University of Melbourne

Author/s:

Clark, T;de Costa, R;Maddison, S

Title:

'The Treaty's Going to Give the Recognition that this Wasn't Right' - Optimism and Pessimism in Non-Indigenous Attitudes to Treaties in Australia

Date:

2019-11-02

Citation:

Clark, T., de Costa, R. \& Maddison, S. (2019). 'The Treaty's Going to Give the Recognition that this Wasn't Right' - Optimism and Pessimism in Non-Indigenous Attitudes to Treaties in Australia. JOURNAL OF INTERCULTURAL STUDIES, 40 (6), pp.665-680. https:// doi.org/10.1080/07256868.2019.1675615.

Persistent Link:

http://hdl.handle.net/11343/292081 